\title{
Financial performance of Nepalese insurance companies
}

\author{
Sumit Pradhan ${ }^{1^{*}}$, Poshan Dahal ${ }^{2}$ \\ *Corresponding author, e-mail: sumitpradhan@uniglobe.edu.np
}

\begin{abstract}
This study examines the financial performance of Nepalese insurance companies. The dependent variables are return on assets and earnings per share while independent variables include insurance premium, firm size, current ratio and solvency ratio. Twenty-one insurance companies among them 8 are life insurance and 13 are non-life insurance companies with 105 observations for the period of 2070/71 to 2074/75, were selected for this study. The data were collected from insurance and financial statistics published by Beema Samiti and annual reports of the selected Nepalese insurance companies. The correlation coefficient and regression models were estimated to test the significance and importance of liquidity management on financial performance of Nepalese insurance companies.

The results shows that insurance premium has positive impact on return on assets and earning per share. It means that increase in insurance premium leads to increase in return on assets and earnings per share. Likewise, firm size has positive impact on return on assets and earning per share. It indicates that increase in firm size leads to increase return on assets and earnings per share. Similarly, current ratio has negative impact on return on assets. It means that increase in current ratio leads to decrease in return on assets. Likewise, solvency ratio has negative impact on return on assets. It indicates that increase in solvency ratio leads to decrease in return on assets. Similarly, current ratio have positive impact on return on assets. It means that increase in current ratio leads to increase in earnings per share. Likewise, solvency ratio has positive impact on earnings per share. It indicates that higher solvency ratio, higher would be the earnings per share. The study also concludes that insurance premium followed by current ratio and firm size is the most influencing factor that explains liquidity management and financial performance of Nepalese insurance companies.
\end{abstract}

Keywords: Liquidity management, firm performance, return on assets, earnings per share, insurance premium, firm size, current ratio and solvency ratio.

\section{Introduction}

The liquidity management duty is to determine the needs for funds to meet financial obligation and ensure the availability of cash or collateral to fulfill those needs as at when due, this is done by coordinating the various sources of funds available to the institution under normal and stressed condition (Chen and Wong, 2004). Niresh (2012) explained that the banking liquidity management is simply to meet financial commitment whether it is withdrawing from a current from a current account or interbank deposit or a maturing issues of commercial paper.

Insurance liquidity means an insurance having money where they need it particularly to satisfy the withdrawal needs of the customers (Wasiuzzaman and Tarmizi, 2010). Liquidity management is very important

\footnotetext{
${ }^{1}$ Uniglobe College, Pokhara University, Kathmandu, Nepal.

${ }^{2}$ Uniglobe College, Pokhara University, Kathmandu, Nepal.
} 
for every organization that means to pay current obligations on business, the payment obligation includes operating and financial q that are short term how ever increasing in long term debt (Saleem and Reheman, 2011). The business has adequate liquid assets in the direction to meet payment programs by compare the cash and near cash among payment obligations on the other side. If the coverage of current liabilities by cash and near cash is insufficient, it indicates that business might find difficulties in meeting immediate financial liabilities (Olagunju et al., 2011).

Managing liquidity risk is to insure the insurance companies own liquidity so that the company can continue to serve its function (Vossen and Ness, 2010). The assessment of the liquidity management in relation to performance becomes imperative as a result of insurance market review in 2009. Theoretical studies and empirical evidence have shown that countries with better developed financial system enjoy faster and more stable long-run growth of which insurance companies contribute (Biet, 2003).

Bouwknegt and Pelsser (2002) opined that at establishing the liquidity risk and its effect of financial performance of listed insurance companies. The study also found that operational, market and credit risks has negative effect on the financial performance of these companies. Profitability and liquidity are effective indicators of the corporate health and performance of not only insurance companies, but all profit-oriented Ventures. The cash assets generally consist of receivables from customers and inventories of complete goods and unprocessed materials (Bhunia, 2012). Liquidity plays a crucial role in successful operation of a banking and insurance business. Every stakeholder is interested in the liquidity position of an insurance company. Thus, banking and insurance firms should safeguard that it does not hurt from lack of or excess liquidity to cover up its short term obligations (Kurawa and Abubakar, 2014). Likewise, Gonga and Sasaka (2017) found that liquidity had an insignificantly positive impact on firm's financial performance.

Molyneux and Thornton (1992); Goddard et al. (2004) found a diverse evidence of a negative relationship between the two variables for European banks in late 1980's and mid-1990's respectively. According to Adebayo et al. (2011), there is significant relationship between liquidity and profitability. According to Mathuva (2009), there is positive relationship between profitability and liquidity of insurance company in Kenya. Similarly, Bagchi (2013) found that there is a negative relationship between the measures of liquidity management and firms' profitability. Bank's liquidity is positively related to profitability and negatively related to the size of the bank and interest margin (Vodova, 2013). Al-Tamini and Obeidat (2013); Lartey et al. (2013) revealed that there is positive relationship between liquidity management and profitability. Likewise, Ericsson and Renault (2005) developed a structural bond valuation model simultaneously capture liquidity and credit risk. The model implies that renegotiation in financial distress is influenced by the illiquidity of the market for distressed debt.

Ramzam and Zafar (2014) revealed statistically positive and significant relationship of assets base or size of the bank with liquidity risk in the estimated hypothetical model. Likewise, Berger and Goldberg (2004) argued that there is positive relationship between bank size and profitability. Profitability is more likely to improve emulating industry best practice in terms of technology and management structure than by increasing the size. Similarly, Demirguc-Kunt(1998) found that foreign insurance and banks have more profitability than domestic banks in developing countries while in developed countries. Same as, Chirwa (2003) examined that 
there is a negative relationship between profitability and capital adequacy ratio and gearing ratio. Likewise, Chen et al. (2010) showed that bank size, liquidity and interest income have positive effect on the bank's profitability, but credit risk and loans have a negative effect on the banks' profitability.

In the context of Nepal, stability of insurance sector helps to maintain stability in the economy (Baral, 2005). Likewise, Joshi (2004) found that the liquidity and insurance companies are positively related to insurance profitability. Same as, Maharjan (2007) revealed that the capital adequacy and liquidity is positively associated with the insurance profitability. Likewise, Shrestha (2012) found positive and significant association between liquidity and profitability of banks of Nepal. Similarly, Pradhan and Shrestha (2016) revealed negative relationship between quick ratio and profitability measured in terms of return on equity. Likewise, Poudel (2012) found an inverse impact on banks' financial performance; however the default rate is the most predicator of bank and financial institutions performance. Same as, Jha (2012) showed that the liquidity position has negative impact on financial performance.

The major purpose of study is to examine the financial performance of Nepalese insurance companies. More specifically, it determines the relationship of current ratio, gross premium, firm size and solvency ratio on return on assets and earnings per share of Nepalese insurance companies.

\section{Methods}

The study is based on secondary data. The necessary secondary data are collected from Annual financial statements Insurance Companies and Annual reports of the selected Nepalese insurance companies. The data have been collected for the period of $2070 / 71$ to $2074 / 75$, leading to a total of 105 observations. This study is based on descriptive and causal comparative research designs. Table: 1 shows the number of insurance companies selected for the study along with study period and the number of observations.

Table 1: Number of insurance companies selected for the study along with study period and the number of observations

\begin{tabular}{lcc}
\hline \multicolumn{1}{c}{ Name of Insurance Companies } & Study Period & Observation \\
\hline Rastra Beema Sanstan & $2070 / 71$ to 2074/75 & 5 \\
Prime Life Insurance Company Limited & $2070 / 71$ to $2074 / 75$ & 5 \\
National Life Insurance Company Limited & $2070 / 71$ to 2074/75 & 5 \\
Asian Life Insurance Company Limited & $2070 / 71$ to 2074/75 & 5 \\
Guras Life Insurance Company Limited & $2070 / 71$ to 2074/75 & 5 \\
Nepal Life Insurance Company Limited & $2070 / 71$ to 2074/75 & 5 \\
Life Insurance Corporation Limited & $2070 / 71$ to 2074/75 & 5 \\
Met Life Insurance Company Limited & $2070 / 71$ to 2074/75 & 5 \\
NLG Insurance Company Limited & $2070 / 71$ to 2074/75 & 5 \\
Siddhartha Insurance Limited & $2070 / 71$ to 2074/75 & 5 \\
United Insurance Company Limited & $2070 / 71$ to 2074/75 & 5 \\
Sagarmatha Insurance Company Limited & $2070 / 71$ to 2074/75 & 5 \\
Himalayan General Insurance Company Limited & $2070 / 71$ to 2074/75 & 5 \\
IME General Insurance Company Limited & $2070 / 71$ to 2074/75 & 5 \\
Prudential Insurance Company Limited & $2070 / 71$ to 2074/75 & 5
\end{tabular}


Everest Insurance Company Limited

2070/71 to $2074 / 75$

Lumbini General Insurance Company Limited

$2070 / 71$ to $2074 / 75$

Neco Insurance Limited

$2070 / 71$ to $2074 / 75$

Prabhu Insurance Company Limited

2070/71 to $2074 / 75$

Nepal Insurance Company Limited

$2070 / 71$ to $2074 / 75$

Premier Insurance Company Limited

$2070 / 71$ to $2074 / 75$

Thus, this study is based on the 105 observations.

The Model

The study assumes that the insurance performance depends upon different variables. The dependent variables selected for the study are earning per share and return on assets. Similarly, the selected independent variables are firm size, current ratio, solvency ratio and insurance premium. To explain the influence of the independent variables on the dependent variables, multiple regression analysis was used. Therefore, the following model equation is designed to test the hypothesis.

Performance $=\mathrm{f}$ (firm size, current ratio, solvency ratio and insurance premium).

More specifically, the given model has been segmented into following models;

$\mathrm{ROA}=\beta 0+\beta 1 \mathrm{FS}+\beta 2 \mathrm{CR}+\beta 3 \mathrm{SOL}+\beta 4 \mathrm{IP}+\mathrm{e}$

$E P S=\beta 0+\beta 1 F S+\beta 2 C R+\beta 3 S O L+\beta 4 I P+e$

In the above model, the dependent variable is the earning per share indicated by the earning available to equity holder to number of share.

Where,

ROA = Return on assets, defined as the profit after tax to average assets, in percentage.

EPS= Earnings per share, defined as the earning available to equity holder to number of share.

FS= Firm size, defined as the total size of assets.

$C R=$ Current ratio, define as current assets divided by current liabilities.

SOL= Solvency ratio, defined as the company's ability to meet its debt obligations

$\mathrm{IP}=$ Insurance Premium, defined as total premium collected.

The following section describes the independent variables used in this study along with hypotheses.

Current ratio

Current ratio indicates the bank's market liquidity and measures the ability of bank to meet the short term obligation. It is calculated by dividing current assets by current liabilities (Bhunia, 2012). There is positive and statistically significant association between current ratio and bank profitability (Ismail, 2016). There is a positive relationship between the firm's profitability and liquidity levels as measured by current ratio (Ajanthan, 2013). According to Muda et al. (2013), there is positive relationship between the liquid ratio and profitability of the firm. Similarly, Godwin and Moses (2015) indicated that the liquidity management indicator i.e. liquid assets to total asset ratio have positive impact on the bank profitability. Same as, Bourke (1989) found positive and significant relationship between liquidity risk and profitability. Based on it, this study develops the following hypothesis:

H1: There is a positive relationship between current ratio and financial performance. 
Firm size

Size refers to bank size that is considered as total assets. Larger company has larger market share and market power in respect of customers and volume of investment (Berger and Goldberg, 1997). Likewise, Niresh (2012) concluded that firm size has positive impact on performance of firm. Similarly, Butt and Hasan (2009) determined a positive and significant relationship between firm size and financial performance. According to Sufain et al. (2009), there is a positive impact of firm size on performance. Similarly, the effect of bank size on profitability is found to be positive (Simrlock, 1985). Firms' size has a strong positive affiliation with profitability (Bagchi, 2013). Based on it, this study develops the following hypothesis:

$\mathrm{H} 2$ : There is a positive relationship between firm size and financial performance.

\section{Insurance premium}

Premium is the amount of money that an individual or a business must pay for an insurance policy (Chaudhari and Kiran, 2011). Likewise, Burca and Batrinca (2014) found that there is positive influence of premium on the return on assets. According to Kaya (2015), profitability of non-life insurance companies is statistically and positively related to the premium collected. Similarly, Jibran et al. (2016) found that there is positive relationship between premium and profitability. Same as, Suheyli (2015) found that premium has a positive and statistically significant relationship with profitability. Likewise, Lire (2016) revealed a positive relationship between premium and profitability. Based on it, this study develops the following hypothesis:

$\mathrm{H} 3$ : There is a positive relationship between insurance premium and financial performance.

Solvency ratio

Solvency ratio is the ability of a company to meet its long term fixed expenses and to accomplish long term expansion growth. A solvency ratio greater than $20 \%$ is considered financially healthy. The higher ratio better equipped a company is to pay off its debts and survive in the long term (Bawa, 2013). According to Gulati and Jain (2011), there is positive and significant relationship of solvency ratio and financial performance. Similarly, Chaudhary and Kiran (2011) observed a positive relationship of solvency with financial performance of insurance companies. Likewise, Khidmat and Rehman (2014) showed that the solvency ratio has positive and highly significant impact on the financial performance of firms. Same as, Obudho (2014) established that solvency risk was positively affect the financial performance of insurance companies in Kenya. Based on it, this study develops the following hypothesis:

$\mathrm{H} 4$ : There is a positive relationship between the solvency ratio and financial performance.

\section{Results and Discussion}

\section{Descriptive statistics}

This table shows the statistics of the dependent variable and independent variable. Dependent variables are ROA (return on assets as net income divided by total assets) and EPS (earning per share as net income after tax is divided a total number of shareholders) and independent variables are IP (insurance premium specified as premium collected), FS (firm size specified as total assets of firm), CR (Current ratio specified as current assets divided by current liabilities), SOL (Solvency ratio specified as total equity divided by total liabilities). The described statistics are based on the data from 21 sample insurance companies with 
105observations for the period 2070/71 to 2074/75. Table 2 presents the descriptive statistics of selected dependent and independent variables during the period 2070/71 to 2074/75.

Table 2: Descriptive statistics for selected Nepalese insurance companies

\begin{tabular}{cccccc}
\hline Variables & N & Minimum & Maximum & Mean & Std. Deviation \\
\hline ROA & 105 & 10 & 22.67 & 15.58 & 9.91 \\
EPS & 105 & 0.00 & 100.81 & 34.36 & 20.48 \\
IP & 105 & 14.34 & 22.30 & 19.25 & 1.62 \\
FS & 105 & 18.52 & 26.84 & 21.63 & 1.51 \\
CR & 105 & 0.04 & 27.60 & 2.30 & 3.56 \\
SOL & 105 & 9.89 & 26.44 & 12.12 & 6.16 \\
\hline
\end{tabular}

\section{Correlation analysis}

Having indicated the descriptive statistics, Pearson correlation coefficients are computed and the results are presented in Table 3 . This table shows the Pearson correlation coefficients among different dependent variables and independent variables. Dependent variables are ROA (return on assets as net income divided by total assets) and EPS (earning per share as net income after tax is divided a total number of shareholders) and independent variables are IP (insurance premium specified as premium collected), FS (firm size specified as total assets of firm), CR (Current ratio specified as current assets divided by current liabilities) and SOL (Solvency ratio specified as total equity divided by total liabilities.

Table 3: Pearson correlation coefficients matrix

\begin{tabular}{crrrrrr}
\hline Variables & \multicolumn{1}{l}{ ROA } & \multicolumn{1}{l}{ EPS } & \multicolumn{1}{c}{ IP } & FS & CR & SOL \\
\hline ROA & 1 & & & & & \\
EPS & -0.068 & 1 & & & & \\
IP & 0.148 & $0.303^{* * *}$ & 1 & & & \\
FS & -0.001 & -0.111 & 0.119 & 1 & & \\
CR & -0.125 & $0.274^{* * *}$ & $0.317^{* *}$ & 0.127 & 1 & \\
SOL & -0.140 & 0.167 & 0.131 & $0.234^{*}$ & $0.311^{* * *}$ & 1 \\
\hline
\end{tabular}

Note: The asterisk signs $\left({ }^{* *}\right)$ and $\left(^{*}\right)$ indicate that the results are significant at one percent and five percent levels respectively.

Table 3 shows that there is positive relationship between insurance premium and earning per share. It indicated that higher the insurance premium, higher would be the earning per share. Similarly, firm size is negatively related to with earning per share. It indicates that increase in firm size leads to decrease in earnings per share. Likewise, current ratio is positively correlated to earning per share. It indicates that increase in current ratio leads to increase in earnings per share. Similarly, solvency ratio is positively related to earning per share. It indicates that higher the solvency ratio, higher would be the earnings per share.

The positive relationship between insurance premium and return on assets also observed. It indicated that higher the insurance premium, higher would be the return on assets. Similarly, firm size is negatively related to with return on assets. It indicates that increase in firm size leads to decrease in return on assets. Likewise, current ratio is negatively correlated to return on assets. It indicates that increase in current ratio leads to decrease in return on assets. Similarly, the solvency ratio is negatively related to earnings per share. It indicates that higher the solvency ratio, the lower would be the return on assets. 


\section{Regression analysis}

Having indicated the Pearson correlation coefficient, the regression analysis has been carried out and the results are presented on table 4. More specifically, it shows the regression results of insurance premium, firm size, current ratio and solvency ratio in the financial performance of Nepalese insurance companies.

Table 4: Estimated regression results of insurance premium, firm size, current ratio, and solvency ratio on return on assets

\begin{tabular}{crrrrrrrr}
\hline Model & Intercept & \multicolumn{1}{l}{ IP } & FS & CR & SOL & $\begin{array}{c}\text { Adj. } \\
\text { R_bar }\end{array}$ & SEE & F \\
\hline $\mathbf{1}$ & 2.529 & 0.265 & & & & 0.012 & 2.8989 & 2.3 \\
& $(0.749)$ & $(1.519)$ & & & & & & \\
$\mathbf{2}$ & 2.609 & & 0.164 & & & 0.24 & 2.6812 & 5.32 \\
& $(6.293)^{* *}$ & & $(1.721)$ & & & & & \\
$\mathbf{3}$ & 2.815 & & & -0.102 & & 0.006 & 2.9029 & 1.636 \\
& $(8.334)^{* *}$ & & & $(-1.279)$ & & & & \\
$\mathbf{4}$ & 2.788 & & & & -0.098 & 0.01 & 2.8965 & 2.04 \\
& $(8.773)^{* *}$ & & & -0.155 & & 0.028 & 2.8701 & 2.99 \\
$\mathbf{5}$ & -3.985 & 0.365 & & $-1.431)$ & & \\
& $(-1.121)$ & $(1.98)^{*}$ & & $(-1.864)$ & & & & \\
$\mathbf{6}$ & 3.274 & & & -0.066 & -0.104 & 0.009 & 2.8985 & 3.98 \\
& $(6.666)^{* *}$ & & $-0.78)$ & $-(1.367)$ & & & \\
$\mathbf{7}$ & -4.211 & 0.374 & 0.002 & -0.156 & & 0.027 & 2.8719 & 2.95 \\
$\mathbf{8}$ & $(-0.821)$ & $(2.038)^{*}$ & $(0.012)$ & $(-1.864)$ & & & & \\
& -5.185 & 0.378 & 0.045 & -0.128 & -0.087 & 0.031 & 2.8659 & 1.821 \\
\hline
\end{tabular}

Notes:

i. $\quad$ Figures in parenthesis are t-values

ii. The asterisk signs $(* *)$ and $(*)$ indicate that the results are significant at one percent and five percent level respectively.

iii. $\quad$ Return on assets is dependent variable.

The results are based on panel data of 21 insurance companies with 105 observation for the period of $2070 / 71$ to $2074 / 75$ by using regression model. The model is EPS $=\alpha+\beta_{1} \mathrm{LEV}+\beta_{2} \mathrm{FS}+\beta_{3} \mathrm{CR}+\beta_{4} \mathrm{SOL}+\beta_{5}$ IP +e where EPS(earning per share as net income after tax is divided total number of shareholders) is the dependent variable and independent variable are IP (insurance premium specified as natural logarithm of premium collected), FS (firm size specified as natural logarithm of total assets of firm), CR (Current ratio specified as current assets divided by current liabilities) and SOL (Solvency ratio specified as total equity divided by total liabilities). Table 4 shows that beta coefficients for insurance premium are positive with return on assets. It indicates that insurance premium has positive impact on return on assets. This finding is consistent with the findings Kaya (2015). Likewise, the beta coefficients for firm size are positive with return on assets. It indicates that firm size has positive impact on return on assets. This finding is similar to Butt and Hassan (2009). Likewise, the beta coefficients for current ratio are negative with return on assets. It indicates that current ratio has positive impact on return on assets. This finding is consistent with the findings Bourke (1989). Similarly, the beta coefficients for solvency ratio are negative with return on assets. It indicates that solvency ratio has negative impact on return on assets. This finding is similar to the finding of Obudho (2014). 
Table 5: Estimated regression results of insurance premium, firm size, current ratio, and solvency ratio on earning per share

\begin{tabular}{|c|c|c|c|c|c|c|c|c|}
\hline Model & Intercept & IP & FS & $\mathbf{C R}$ & SOL & $\begin{array}{c}\text { Adj. } \\
\text { R_bar }\end{array}$ & SEE & F-Value \\
\hline $\mathbf{1}$ & $\begin{array}{l}-39.308 \\
(-1.717)\end{array}$ & $\begin{array}{r}3.826 \\
(3.23)^{* *}\end{array}$ & & & & 0.083 & 19.6165 & 10.433 \\
\hline 2 & $\begin{array}{r}66.962 \\
(2.326)^{*}\end{array}$ & & $\begin{array}{r}1.507 \\
(1.135)\end{array}$ & & & 0.003 & 20.4584 & 1.28 \\
\hline 3 & $\begin{array}{r}20.732 \\
(13.336)^{* *}\end{array}$ & & & $\begin{array}{r}1.574 \\
(2.891)^{* *}\end{array}$ & & 0.66 & 19.7983 & 8.35 \\
\hline 4 & $\begin{array}{r}32.616 \\
(14.647)^{* *}\end{array}$ & & & & $\begin{array}{r}0.821 \\
(1.718)\end{array}$ & 0.018 & 20.2974 & 2.95 \\
\hline 5 & $\begin{array}{r}18.96 \\
(0.556)\end{array}$ & $\begin{array}{r}3.222 \\
(2.639)^{* *}\end{array}$ & $\begin{array}{r}2.288 \\
(1.823)\end{array}$ & $\begin{array}{r}1.233 \\
(2.214)^{*}\end{array}$ & & 0.13 & 19.1102 & 6.174 \\
\hline 6 & $\begin{array}{r}26.834 \\
(8.032)^{* *}\end{array}$ & & & $\begin{array}{r}1.338 \\
(2.334)^{*}\end{array}$ & $\begin{array}{r}0.686 \\
(1.327)\end{array}$ & 0.074 & 19.7182 & 3.75 \\
\hline 7 & $\begin{array}{r}70.631 \\
(2.365)^{*}\end{array}$ & & $\begin{array}{r}2.003 \\
(1.475)\end{array}$ & $\begin{array}{r}1.409 \\
(2.465)^{*}\end{array}$ & $\begin{array}{r}0.775 \\
(1.497)\end{array}$ & 0.084 & 19.6043 & 4.39 \\
\hline 8 & $\begin{array}{r}3.374 \\
(2.764)^{* *}\end{array}$ & $\begin{array}{r}9.753 \\
(2.268)^{*}\end{array}$ & $\begin{array}{r}2.172 \\
(1.651)\end{array}$ & $\begin{array}{r}0.928 \\
(1.598)\end{array}$ & $\begin{array}{r}0.795 \\
(1.584)\end{array}$ & 0.141 & 18.9843 & 4.423 \\
\hline
\end{tabular}

Notes:

i. $\quad$ Figures in parenthesis are $t$-values

ii. $\quad$ The asterisk signs $\left({ }^{*}\right)$ and $(*)$ indicate that the results are significant at one percent and five percent level respectively.

iii. Earnings per share is dependent variable.

Table 4 shows that beta coefficients for insurance premium are positive with earning per share. It indicates that insurance premium has positive impact on earnings per share. This finding is consistent with the findings Lire (2016). Likewise, the beta coefficients for firm size are positive with earning per share. It indicates that firm size has positive impact on earnings per share. This finding is similar to Simrlock (1985). Likewise, the beta coefficients for current ratio are positive with earning per share. It indicates that current ratio has positive impact on earnings per share. This finding is consistent with the findings Bourke (1989). Similarly, the beta coefficients for solvency ratio are positive with earning per share. It indicates that solvency ratio has positive impact on earnings per share. This finding is similar to the finding of Gulati and Jain (2011).

\section{Conclusion}

The issue of liquidity management is receiving serious attention all over the world especially with the current financial situations and the state of the world economy. Some of the striking corporate goals include the need to maximize profit maintaining high level of liquidity in order to guarantee safety. Many study like; Olagunji et al., (2011) and Kurawa and Abubakar (2014) have established that profitability and liquidity management need purposeful attention from adequate financial intermediation. Liquidity is the statistically significant predictor of firms' profitability. Every stakeholder has interest in the liquidity situation of insurance company. So, insurance firm should ensure that it does not suffer from lack of or excess liquidity to cover up its short-term obligations. This study attempts to examine the financial performance of Nepalese insurance companies. The study is based on secondary data of 21 insurance companies of 105 respondents.

The study shows that insurance premium, firm size, current ratio and solvency ratio have positive impact on earnings per share. Likewise, insurance premium, firm size have positive impact with return on 
assets. However, current ratio, and solvency ratio have negative impact with return on assets. The study concludes that higher the insurance premium and current ratio leads to higher would be the financial performance. The study also concludes that insurance premium followed by current ratio and firm size is the most influencing factors that explains the financial performance of Nepalese insurance companies.

\section{Acknowledgements}

The authors would like to thank Branch Managers of various insurance companies for providing the additional information which are hard to find in the annual report and different publications.

\section{Declaration of conflicting interests}

The authors declare no conflict of interest.

Funding

This research received no grant from any funding agency.

Author contributions

Conceptualization: Pradhan. Methodology: Pradhan. Software: Dahal. Validation: Dahal. Formal Analysis:

Pradhan; Dahal. Investigation: Dahal. Data Curation: Dahal. Writing - Original Draft: Dahal. Writing - Review \& Editing: Dahal. Visualization: Pradhan. Supervision: Pradhan.

\section{Ethical statement}

This research did not require ethical approval as it does not involve any human or animal experiment.

Data availability statement

Data will be available upon reasonable request from the corresponding author.

ORCID information

Sumit pradhan, ORCID: 0000-0002-9435-2490

\section{References}

Adebayo, O., David, A. O., \& Samuel, O. O. (2011). Liquidity management and commercial banks' profitability in Nigeria. Research Journal of Finance and Accounting, 1(2), 7-8.

Ajanthan, A. (2013). A nexus between liquidity and profitability. European Journal of Business and Management, $5(7), 221-237$.

Al-Tamini, K., \& Obediat, S. (2013). Determinants of capital adequacy of commercial banks of Jordan an empirical study. International Journal of Academics Research in Economics and Management Sciences, 2(4), 78-85.

Angbazo, L. (1997). Commercial bank net interest margins, default risk, interest-rate risk, and off-balance sheet banking. Journal of Banking and Finance, 21 (1), 55-87.

Bagchi, B. (2013). Liquidity-profitability relationship: Empirical evidence from Indian fast moving consumer goods firms. International Journal of Applied Management Science, 5(4), 355-376.

Baral, K. J. (2005). Health check up of commercial banks in the framework of CAMEL: A case study of joint venture of banks in Nepal. Health check up of the journal of Nepalese Business Studies, 2(1), 41-55.

Bawa, S., \& Samiya, C. (2013). Financial performance of life insurance Company in Indian insurance industry. Pacific Business Review International, 6(5), 34-78.

Berger, A., \& Goldberg, S. (2004). The dynamics of market entry: The effect of merger and acquisition on entry in the banking and financial institution. The Journal of Business, 23(1), 797-834.

Berrios, M. R. (2013). The relationship between bank credit risk and profitability and liquidity. The International Journal of Business and Finance Research, 3(2), 17-25.

Bhunia, B. (2012). How far India has gone down the road towards financial integration with US since subprime crisis? An economic analysis. Journal of finance and Banking Management, 1(1), 150-160.

Biet, M. (2003). Liquidity and asset liability management in saving services. Journal of Finance and Accounting, 3(2), 123-145.

Bourke, P. (1989). Concentration and other determinants of banks profitability in Europe, North America \&Australia. Journal of Banking and Finance, 13(1), 65-79 
Bouwknegt, P. and Pelsser, A. (2002). Market value of insurance contracts with profit sharing. Journal of Risk sharing Finance. 1(1), 60-64.

Burca, A. M., \& Batrinca, G. (2014). The determinant of financial performance in the Romanian insurance market. International Journal of Academic Research in Accounting, Finance and Management Sciences, 4(1), 299308.

Butt, S. A., \& Hasan, A. (2009). Impact of ownership structure and corporate governance on capital structure of Pakistani listed companies. International Journal of Business and Management, 4(2), 50-57.

Chaudhary, S., \& Kiran, P. (2011) Life insurance industry in India: Current scenario. International Journal of Management and Business Studies, 3(1), 146-150.

Chen, R., \& Wong, K. A. (2004). The determinants of financial health of Asian insurance companies. The Journal of Risk and Insurance, 71(3), 469-99.

Chirwa, E.W. (2003). Determinants of commercial banks in Malawi: A co-integration approach. Journal of Banking andFinance, 13(5), 565-571.

Cudiamat, A., \& Siy, J. S. (2017). Determinants of profitability in life insurance companies: Evidence from the Philippines. Essays in Econoic and Business Studies, 2(1), 165-175

Demirguc-Kunt A, Levine, R., \& Min, H. G. (1998). Opening to foreign banks: Issues of stability, efficiency and growth. International Journal of Academic Research in Economics and Management Sciences, 2(1), 4050.

Ericsson, J., \& Renault, O. (2005). Liquidity and credit risk. International Journal of Management, 15(2), 41-50.

Ezeoha, A. E. (2008). Firm size and corporate financial-leverage choice in a developing economy: Evidence from Nigeria. The Journal of Risk Finance, 9 (4), 351-364.

Goddard, J., Molyneux, P., \& Wilson, J. (2004). The profitability of European bank: A cross sectional and dynamic panel analysis. The Manchester School, 72(3), 363-381.

Godwin, E. B., \& Moses, C. E. (2015). Banks profitability and liquidity management: A case study of selected Nigerian deposit money banks. International Journal of Economics, Commerce and Management, 3(4), 1-24.

Gonga, M., \& Sasaka, P. (2017). Determinants of financial performance of insurance firms: A survey of selected insurance firms in Nairobi Country. The strategic Journal of Business and Change Management, 4(4), 123-145.

Gulati, N. C., \& Jain, C. M. (2011). A review of solvency margin in Indian insurance company. International research and Review, 1(8), 561-566.

Ismail, R. (2016). Impact of liquidity on profitability of Pakistani firms. International Journal of Innovation and Applied Studies, 14(2), 304-314.

Jha, S., \& Hui, X. (2012). A comparison of financial performance of commercial banks: A case study of Nepal. African Journal of Business Management, 6(25), 7601-7611.

Jibran, Q. M., Masood, S., \& Aslam, K. (2016). Determinants that affect the profitability of non-life insurance companies. Research Journal of Recent Sciences, 5(4), 6-11.

Joshi, R. K. (2004). Liquidity ratio and profitability of the banks. The Journal of Nepalese Business Studies, 2(4). 12-18.

Kaya, E. (2015). The effect of firm specific factors on the profitability of non-life insurance companies in Turkey. International Journal of Financial studies, 3(4), 510-529.

Ketan, M. (2016). The determinants of financial performance in life insurance sector in India. Asian Journal of Empirical Research, 6(10), 261-269.

Khidmat, W. B., \& Rehman, M. U. (2014). Impact of liquidity and solvency on profitability. Economics Management Innovation Journal, 6(3), 184-129. 
Kurawa, J. M., \& Abubakar, A. (2014). An evaluation of the impact of Liquidity on the profitability of Nigerian banks. Journal of Management, 2 (7), 2347-8217.

Lartey, V. C., Antwi, S., \& Boadi, E. K. (2013). The relationship between liquidity and profitability listed Insurance in Ghana. International Journal of Business and Social Science, 4(3), 48-56.

Lire, A. (2016). Determinants of profitability of private insurance companies in Ethiopia. Journal of Poverty, Investment and Development, 14(12), 85-92.

Magar, G.T. (2016). Liquidity management and bank profitability: A case of Nepalese financial institution. Nepalese Journal of Management, 3(4) 55-70.

Maharjan, M. (2007). Impact of liquidity in the economy. Journal of Management, 9(2). 34-41.

Mathuva, D. (2009). The influence of working capital management components on corporate profitability: A survey on Kenyan listed firms. Research Journal of Business Management, 3(1), 1-11.

Molynuex, P., \&Thornton, J. (1992). Determinants of European bank profitability. Journal of Banking and Finance, 16(1), 1173-1178.

Muda, M., Shaharuddin, A., and Embaya, A. (2013). Profitability determinants and the impact of global financial crisis: A panel data analysis of Malaysian banks. Research Journal of Finance and Accounting, 4(7), 121130.

Niresh, J.A. (2012). Trade-off between liquidity and profitability: A study of selected manufacturing firms in SriLanka. Journal of Arts, Science and Commerce, 3(4), 34-40.

Obudho, A. R. (2014). The relationship between financial risk and financial performance of insurance companies in Kenya. International Journal of Business and Management, 4(2), 50-57.

Olagunju, A., Adeyanju, O. D., \& Olabode, O. S. (2011). Liquidity management and commercial banks' profitability in Nigeria. Research Journal of Finance and Accounting, 2 (7), 2222-2847.

Poudel, R. P. (2012). The impact of credit risk management on financial performance of commercial banks in Nepal. International Journal of Arts and Commerce, 3(2), 1-10.

Pradhan, R. S., \& Shrestha, D. (2016). Impact of liquidity on bank profitability in Nepalese commercial banks. Nepalese Journal of Business, 3(4), 1-15

Ramzam, P., \& Zafar, M. I. (2014). Liquidity risk management in Islamic banks: A study of listed manufacturing companies in Sri Lanka, International Journal of Technology Exploration and Learning, 1(2), 40-50.

Saleem, Q., \& Reheman, R. (2011). Impact of liquidity of liquidity ratio on profitability; interdisciplinary. Journal of Research in Business, 1(7), 95-98.

Scott, J. W., \& Arias, J. C. (2011). Banking profitability determinants. Business Intelligence Journal, 4(2), 209-230.

Shamshi, A.F., \& Salman, N. A. (2015). Impact of financial leverage on firm's profitability: An investigation from cement sector of Pakistan. Research Journal of Finance and Accounting, 6(7), 75-80.

Sheel, A. (1994). Determinants of capital structure choice and empirics on leverage behavior: A comparative analysis of hotel and manufacturing firms. Hospitality Research Journal, 17(4), 3-16.

Shrestha, B. P. (2012). Impact of liquidity on profitability of financial institution of Nepal. Nepalese Journal of Management, 2(1), 27-38.

Smirlock, M. (1985). Evidence on the non relationship between concentration and profitability on banking. Journal of Money, Credit and Banking, 17(1), 69-83.

Smith, B. (2002). Trade-off between liquidity and profitability. International Refereed Research Journal, 3(4), 3440.

Sufian, F. (2011). Profitability of the Korean banking sector: Panel evidence on bank-specific and macroeconomic determinants. Journal of Economic and Management, 7(1), 69-83.

Suheyli, R. (2015). Determinants of insurance company's profitability in Ethiopia. Ethiopian Journal of Management and Economics, 2(3), 44-64. 
Titman, S \& Wessles, R. (1988). The determinants of capital structure choice. Journal of Finance, 43(7), 1-19.

Vodova, P. (2013). Determinants of commercial bank liquidity in Hungary. Finansowy Kwartalnik InternetowyeFinanse, 9(3), 64-71.

Vossen, B., \& Ness, R. (2010). Bank liquidity management: Evidence from emerging market. Journal of Finance and Accounting, 2(1), 105-111.

Wasiuzzaman, S., \& Tarmizi, H. (2010). Profitability of Islamic insurance in Malaysia: An empirical analysis. Journal of Islamic Economics, 4(6), 78-90. 